\title{
How Jokowi Communicates with the Public During Covid-19 Crisis: An Analysis of Tweets on Twitter
}

\author{
KADHUNG PRAYOGA \\ Diponegoro University, Indonesia
}

\begin{abstract}
The coronavirus pandemic has caused mass fear and panic in Indonesia. Irrational behaviour is carried out by people ranging from panic buying to violating the government appeals and rules. This condition certainly leads to the importance of disaster communication carried out by an opinion leader. Therefore, the objective of writing this paper is to analyse how the disaster communication was carried out by Jokowi on Twitter during the Covid-19 pandemic. This research was conducted using data from President Jokowi's tweets (@jokowi) related to Covid-19 from January 1, 2020, to April 30, 2020. The number of tweets analysed was 150 tweets related to coronavirus from a total of 290 tweets. These tweets were collected automatically with the help of the Ncapture and NVIVO 12 analysis tools. However, the researcher also re-checked the data manually. The collected data is then encoded using Microsoft Excel. Finally, the data was analysed using quantitative content analysis. The results found that Jokowi has provided a wide variety of information, ranging from socialising policies related to the handling of COVID-19 in Indonesia to the extension of condolences to the affected patients. The use of photos and videos is also carried out by Jokowi to increase public awareness. Unfortunately, disaster communications were not carried out in advance before the pandemic occurred. It was only actively carried out when the pandemic had claimed many victims. Furthermore, coordination with many parties in providing the information is also crucial. Finally, Jokowi should use a hashtag (\#) more often to reach a wider range of tweets.
\end{abstract}

Keyword: Communication, corona, covid-19, Jokowi, Twitter.

\section{INTRODUCTION}

Since the coronavirus outbreak was declared as a global pandemic, it has changed people's lives economically, socially, and psychologically. COVID-19 not only killed people but also caused economic paralysis activity, starting from employment termination, the drop of Indonesian rupiah rate against the US dollar, and soaring prices for basic necessities. It made Indonesia government have various efforts and policies such as work from home, lockdown, the prohibition of annual mass exodus or mudik ban, and physical distancing. The aims was to slow down and reduce the spread of the coronavirus, but there were many commotions occurring everywhere rather than feeling a sense of security and control during the coronavirus outbreak. There were still many people who did not follow the government's appeal. Apart from the fact that people need money to survive, stress and boredom are also faced by the community. The potential for greater negative impacts, such as chaos and high mortality rates even become reality when there was no meaningful action. There is a need for disaster management to deal with all these things and one of the aspects is communication, coordination, and distribution of information (Budi, 2012; Tamitiadini, Dewi, \& Adila, 2019).

Disaster risk can be minimised if the government can use good and effective communication. Thus, people can get information quickly and accurately. Therefore, number of death can be reduced and the impact of the disaster can be minimised (Haddow \& Haddow, 
2009). According to the study conducted by Sosiawan (2014), in Indonesia, the government who was represented by disaster-related institutions did not at the time have a good communication mechanism, therefore the coordination and handling also did not work as expected. Surely, the responsibility to maintain sustainability must certainly be done by President Joko Widodo (Jokowi) as a symbol of the government. As the number 1 person in Indonesia, he is expected to be able to calm the community amid this pandemic. If the communication strategy chosen by Jokowi is ineffective, it will only cause confusion and anxiety from the public. As described by Asteria (2016), public panic can be reduced by statements from credible person.

A leader, according to Rahayu, Asrul and Akbar (2014), should educate the public with the help of the media, before, during, and after the disaster. The method is by addressing the issues and answering the spreading rumours. Especially in this era, people can easily search for information, but unfortunately, there are many hoaxes and uncredible news. This is in line with the study of Syarif, Unde and Asrul (2014) which stated that a hoax occurs because of unclear news sources and it causes panic. Therefore, there is a need for someone to become the central source of information. During this pandemic, Jokowi communicated a lot with the community through social media, one of which was Twitter. Jokowi's action is in congruence with what was stated by Emma Mirza Wati and Wan (2017) that it takes opinion leaders in social media to provide the truth of the news.

Social media selection is one smart move. Through social media, the public will be able to absorb and respond to information at the same time (Purworini \& Sugiyanti, 2012). Moreover, Indonesian people cannot be separated from social media, as revealed by Lestari, Ramadhaniyanto and Wardyaningrum (2018) who called Indonesian people a mediated society. Twitter as one of the communication platforms is well-suited for Jokowi given its speed in spreading information. Twitter is considered to be the most popular due to being able to attract the sympathy and empathy of the community (Kumar \& Sebastian, 2012; Ramadani \& Hilmiyah, 2019). Plus, any discussion that appears on Twitter will become a trending topic and will be brought on other social media platforms. It can be said that Twitter is the main source for educating the public. Even Perdana and Umam (2019) explained that Twitter could influence public opinion with an informative and persuasive communication strategy. Purworini and Sugiyanti (2012) as well as Yuniar (2018) in their study mentioned that the use of social media can facilitate its users to obtain social facilities and can overcome the problem of disseminating disaster information which only stops at several levels of the community. Thus, the researcher wants to see more comprehensively on how Jokowi communicates about the coronavirus pandemic through Twitter.

If we examine more deeply, no one has discussed how the president communicates in handling a pandemic in previous studies. Previous studies only discuss how the institutions under the president such as the Indonesian National Board for Disaster Management (BNPB) and related Ministries communicate. For example, in studies conducted by Roskusumah (2013), Shahrul Nazmi and Kamaliah (2014), Wahyudi and Lubis (2016), Baseri, Jarmie and Anhar (2017), also Rianti and Esfandari (2019). These studies show that communication carried out by state institutions in Indonesia related to disasters have mostly not been effective. It is due to the lack of planning, regarding the message to be conveyed, which causes the message only to be created when a disaster has occurred.

In addition, studies on how a leader communicates in the digital realm have not been popular. It is only limited to Besman, Adiputra and Saputra (2018), but the study is about Jokowi's communication pattern in the vlog; it is not specifically related to the disaster. It is 
similar to a study conducted by Romadhan (2018) and Panuju (2019) on how Jokowi built his branding through videos that he uploaded on YouTube. This was how he communicated and expressed something so that it became self-branding. Furthermore, Cindy and Sari (2019) also described Jokowi's strategy building his self-image on Instagram. Drina and Mansur (2017) analysed Jokowi's communication style, but it was related to what the online media projected about Jokowi's image. There is one study that addressed Jokowi and Twitter, conducted by Ichsani and Amir (2017), but they discussed his social network in general. The research that made Jokowi became the object of research also only developed in studies of political marketing.

Furthermore, studies about communication on social media, especially Twitter, are still widely carried out within the scope of political communication like those conducted by Harlow and Johnson (2011), Sandoval-Almazan and Gil-Garcia (2013), Vergeer and Hermans (2013), and Boynton et al. (2014). Many studies regarding the use of Twitter as a medium of political communication explains that Twitter is an effective medium for conveying political messages. How Jokowi displays his image on social media during the election and after becoming president is the most common study conducted.

In previous studies, the disasters that have been studied were mostly only natural disasters such as floods, droughts, tsunamis, and volcanic eruptions. Nobody has discussed pandemics, especially the coronavirus pandemic. So, the focus of interest in this research is disaster communication carried out on social media by the state leaders. While the locus of interest is Jokowi who in this case is an individual and the state leader who is concerned in handling the coronavirus pandemic. However, this research has a limitation that is only seeing the phenomenon on Twitter, but not yet on other social media platforms such as YouTube or Instagram and whether the message delivered by Jokowi is coherent with the message conveyed by other institutions under him. This research also needs to develop by using framing technique, not only content analysis. So, to develop research on this theme in the future, these suggestions can be accommodated by future researchers.

\section{LITERATURE REVIEW}

By definition, disaster communication is a communicative interaction to reduce disaster risk and increase community responsiveness (Haddow \& Haddow, 2009). Moreover, according to Abunyewah, Gajendran and Maund (2018), disaster communication aims to gain attention, trust to stakeholders, build concessions, increase awareness, and educate society to build disaster resilience. When a disaster occurs, the community is already hit by panic and lack of access to information, so this is why it is important for disaster communication to be present before the disaster, when the disaster occurs, and after the disaster. Well-planned disaster communication has even been proven to be able to reduce the impact of hazards from a disaster (Lindell \& Whitney, 2000; Paton, Smith, Daly, \& Johnson, 2008). For that reason, the community has the certainty of what information must be adhered to so they can take strategic steps to deal with disasters that occur.

Littlejohn and Foss (2008), Nowell and Steelman (2014), with Comfort and Kapucu (2006) even emphasised the need for mutual understanding and removing ego between the sectors when the communication process occurs in disaster management. Otherwise, the information will only add to the anxiety and unclear credibility of the message. Palttala, Boano, Lund and Vos (2012) also revealed the latent problem of disaster communication is that every organisation or institution in a country often generates diverse information. 
Kapucu (2006) and Comfort (2007) even stated the need to build cross-sectoral communication before a disaster strikes to build effective communication when a disaster occurs. If this disaster communication does not go well, then what is at stake is the reputation of the responsible organisation, including the government (Ulmer, Sellnow, \& Seeger, 2007; Coombs, 2012)

Disaster communication in its process is still interpreted to be severely limited and is only done when a disaster occurs. The impact is that the public is overreacting and the government is making rudimentary messages. However, in terms of concept, disaster communication must be designed well in advance of the disaster. Careful planning is needed to produce a disaster message by paying attention to patterns that have already existed. Haddow and Haddow (2009) also consider that disaster messages before a disaster occurs have the most important role in the overall process of disaster communication because they relate to community preparedness when disasters occur. Disaster communication must serve as public healing and recovery of the situation not only before the disaster, but even after the disaster happened. This is in line with Coppola and Maloney (2009) study that found that disaster management is not only related to mitigation, but also preparation, response, and recovery. The communicator's readiness in the form of institutions or individuals to prepare this message will encourage the success of disaster mitigation.

Moreover, it is also necessary to have a trusted communicator to convey information accurately. In the disaster communication model proposed by Rodriguez, Quarantelli and Dynes (2007), it clearly explained that one of the communicators who could influence the audience was political leaders. Besides, due to its broad influence, the target is not limited to the general public, but also stakeholders such as large companies. Nevertheless, disaster communication efforts often experience obstacles because of public distrust in government, ineffective communication channels, and ambiguous messages (Faulkner, Parker, Green, \& Beven, 2007; Raaijmakers, Krywkow, \& van der Veen, 2008; Bowen, 2016). The role and participation of policy makers to communicate with the public is necessary to reduce the impact of disasters (Acar \& Muraki, 2011). Therefore, Takeuchi, Xu, Kajitani and Okada (2012) believe the importance of trust between the messenger and the community. Communities ask for information before disaster strikes and participation from leaders (Kashem, 2006). An opinion leader in disaster management, according to Amarul, Najib and Che Su (2014), also requires good interpersonal communication skills because this is related to emotional intelligence possessed.

According to Palttala et al. (2012), a communicator must also have empathy and openness. A study by Figueroa (2013) also mentioned that in creating a calming effect, communicators need to understand the emotional and social conditions of the community. Besides the communicators, real-time and accurate information are required to produce effective responses in dealing with disasters (Burby, 2006; Zook, Graham, Shelton, \& Gorman, 2010), one of which is the use of Twitter. Twitter is even considered feasible to be a complement to conventional media managed by government organisations (Chatfield \& Brajawidagda, 2013). It takes into consideration that the community is currently very dependent on social media when a disaster occurs. Finau et al. (2018), Yin, Lampert, Cameron, Robinson and Power (2012) with Skinner and Rampersad (2014) found the fact that the use of social media increased drastically when a disaster occurs and this is a revolution in disaster communication. Social media is not present to replace traditional communication patterns, rather to complete it. The use of Twitter is an attempt to answer Figueroa (2013) who stated that one of the communication problems of disaster is poor communication when a disaster 
occurs and after the disaster. Lovari and Bowen (2019) also found that the government tends not to evaluate messages after the disaster because they think the disaster is over.

A few studies of the use of Twitter in communicating disasters were conducted by Waters, Burnett, Lamm and Lucas (2009) and Saleem, Xu and Ruth (2014) who evaluated Twitter as the most widely used social media to disseminate information when disasters occur. The reason is due to the high online involvement of the victims and the wider community, both to collect information and to disseminate it. Nair, Ramya and Sivakumar (2017) also used Twitter to analyse the flood phenomenon that occurred in Chennai, India. The result is that the community overflowed their complaints about the government related to the flood. However, prolonged complaints can cause chaos, so according to Muralidharan, Rasmussen, Patterson and Shin (2011) who reviewed the earthquake in Haiti, the media needs to play the proper framing to minimise chaos. Other similar studies that revealed the link between Twitter and natural disasters were conducted by Hughes and Palen (2009), Palen, Starbird, Vieweg and Hughes (2010), Earle, Bowden and Guy (2011), Murthy and Longwell (2013), Shaw, Burgess, Crawford and Bruns (2013), Tengku, Saodah, Aini Maznina and Rizalawati (2015), De Albuquerque, Herfort, Brenning and Zipf (2015), Takahashi, Tandoc Jr and Carmichael (2015), Mortensen, Hull and Boling (2017), with Neppalli, Caragea, Squicciarini, Tapia and Stehle (2017). These researchers revealed the use of Twitter for disasters such as floods, grass fires, earthquakes, typhoons, and hurricanes.

More specifically, Twitter has also been used by some researchers to study a pandemic. One of the uses of Twitter in a pandemic is to develop bio-surveillance, especially early warning when a pandemic occurs (Polgreen, Chen, Pennock, \& Nelson, 2008; Ginsberg, Mohebbi, Patel, Brammer, Smolinski, \& Brilliant, 2009; Szomszor, Kostkova, \& de Quincey, 2009; Lampos \& Cristianini, 2010; Taylor-Clark, Viswanath, \& Blendon, 2010; Chew \& Eysenbach, 2010; Signorini, Segre, \& Polgreen, 2011). Louis and Zorlu (2012) even explained that Twitter can be used as a tool to predict disease outbreaks. A study by Ao, Zhang and Cao (2014), Jain and Kumar (2015), Al-Garadi, Khan, Varathan, Mujtaba and Al-Kabsi (2016), and Tulloch, Vivancos, Christley, Radford and Warner (2019) even used Twitter to manage tracking and mapping of the occurrence of epidemics such as the location of the areas that have the most affected patients, the most vulnerable areas, and the distribution patterns. However, it can be seen that there has not been a study of disaster communication conducted by a country leader when a pandemic occurs. It is expected that this study can provide a more comprehensive understanding of disaster communication.

\section{METHODOLOGY}

This study that examines disaster communication delivered by the Indonesian president on social media of Twitter was conducted using a quantitative and descriptive approach. The data used was the tweets of President Jokowi in the @jokowi account during the COVID-19 pandemic, starting from January 1, 2020 to April 30, 2020. The assumption of this 4-month selection is because during those months, President Jokowi started tweeting on Twitter regarding COVID-19. January and February were chosen to describe Jokowi's way of communication before the pandemic spread in Indonesia. It covers the early warning system that was established by Jokowi on Twitter. Meanwhile, Jokowi's tweet data in March and April was used to analyse Jokowi's way of communication when the COVID-19 pandemic was widespread in Indonesia. Hence, the tweets were chosen purposively, describing Jokowi's way of communication to the community regarding COVID-19. The number of tweets 
analysed was 150 tweets related to corona out of a total of 290 of Jokowi's tweets during the 4 months. These tweets were collected automatically with the assistance of the Ncapture and NVIVO 12 analysis tools. Nevertheless, the researcher also rechecked the data manually by reading President Jokowi's tweets. This method followed Lewis, Zamith and Hermida (2013) who combined data collection and coding, both manually and automatically.

The data collected was then coded using Microsoft Excel. The coding process was carried out in 3 stages. Firstly, it was conducted by the researcher, in which the coding was manually done by the researcher to classify the message type and video content as one unit of analysis. Second, the researcher asked the assistance of other researchers who were not related to this study to do the coding. Finally, it was checked and an agreement on the coding was reached. The unit of analysis in this study is the number of tweets related to corona and their monthly comparisons, comparison of comments, retweets, and likes per month, the type of message from each tweet, as well as the photos and videos used for the tweets, ranging from video duration, viewers, to types of photos selected. The data that has been grouped was then analysed using the quantitative content analysis technique. Different from qualitative content analysis, quantitative content analysis is more directed towards quantitative descriptions of the visible communication content (Neuendorf, 2002; Riffe, Lacy, \& Fico, 2014). Content analysis was chosen because it can describe the communication content of a person or media (Wimmer \& Dominick, 2000). Supported by Atali and Gürer (2015), content analysis is suitable because it can see the relationship between the content and communication goals, describe the meaning, and focus on quantitative description, meaning the frequency of appearance of the characteristics of existing content. Thus, the data can be analysed using percentages and frequencies. Finally, the data were presented descriptively to provide an overview of the results of the analysis.

\section{RESULTS AND DISCUSSION}

Based on the results of the analysis that has been done, it is known that from January to April 2020, through his Twitter account @jokowi, Jokowi has tweeted 290 tweets. Out of the 290 tweets, 150 tweets are related to COVID-19. A comparison between tweets related to COVID19 and those not is shown in Figure 1.

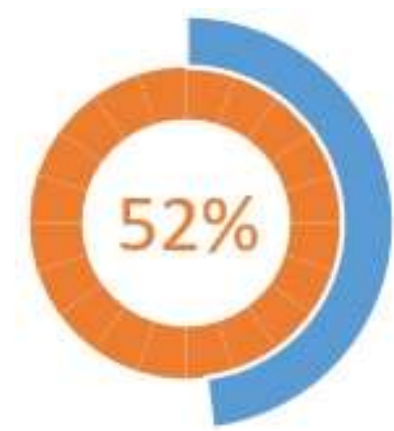

Figure 1: Comparison of total tweets with the number of tweets related to Covid-19

So, the ratio between tweets related to COVID-19 and those not is $52 \%: 48 \%$. Yet, compared on a monthly basis, the difference will be clearly seen. In January, from a total of 71 tweets, there were only 5 tweets related to COVID-19. Turning to February, Jokowi wrote 64 tweets and 17 of them were about COVID-19. In March, the month in which the positive case of COVID-19 increased drastically in Indonesia, Jokowi was also very intense in tweeting. There were a total of 86 tweets and 72 of them were related to Covid-19. The last, in April, 
there were 56 tweets about COVID-19 out of a total of 69 tweets. The comparison of each month is shown in Figure 2.

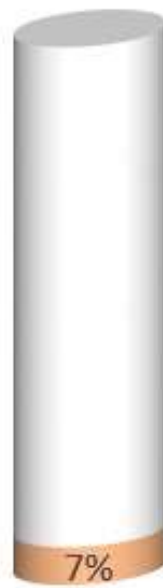

January

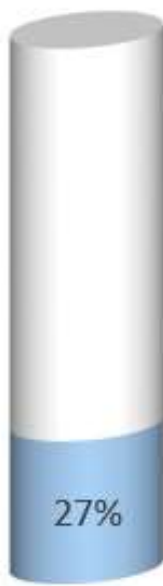

February

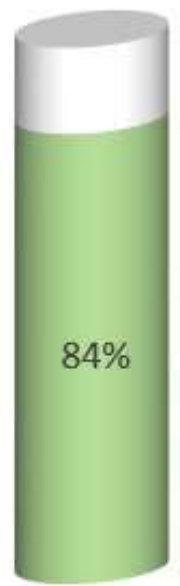

March

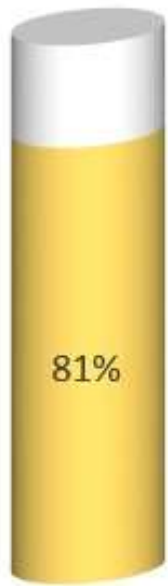

April

Figure 2: Percentage of Jokowi tweet related to COVID-19 from January - April 2020

The disaster communication conducted by Jokowi seems to be just beginning to be massive when a pandemic occurred in March when COVID-19 had infected more people. Thus, Jokowi started to become active as the representation of government to provide information. However, in the early months when COVID-19 began to enter Indonesia in January and February, Jokowi did not share too much information related to this pandemic. A calm and relaxed attitude was seen in those months when in fact, disaster communication must be prepared before the pandemic spreads. When the pandemic was widespread and afterwards, it is seen that, Jokowi as the head of state had still focused his communication on certain phases. In fact, communication when the pandemic has not spread is very important. Andrew, Arlikatti, Chatterjee and Ismayilov (2018) even emphasised the importance of SOPs when a pandemic occurs, especially in the first month of a pandemic. It seems that the message was not very planned. We could learn from research conducted by Moon et al. (2015), Blake, Marlowe and Johnston (2017), Kawasaki et al. (2017), and Avvisati et al. (2019) that emergency plans must be designed, developed, and tested continuously based on the experiences of other or previous pandemics, expert research, and collaborating with other stakeholders to prevent a crisis.

The lack information before pandemic causes a chaotic condition within the community. This is shown by the phenomenon of panic buying behaviour by the community. Both the market and the modern market are filled with people from the upper middle class to buy basic needs so that they feel safe when at home. As a result, the lower class have difficulty buying goods. There is scarcity of goods in the market because they have been bought by those who have money. It is not only basic needs, but masks and hand sanitisers are also becoming a rare item in the market. This circumstance was even used to sell these two items far above the market price. This kind of behaviour basically occurs because there is no definite information provided from the government as the holder of state authority towards the community. The information is abundant and the public cannot filter through all the information because they are scared. Instead of calming the public, the information just makes people anxious. 
However, there is a positive side due to this pandemic. People are now more aware of the importance of health. Before the pandemic, it was very rare to find people who used masks while travelling or just washing hands when in a public place. With the corona pandemic, all these bad habits changed. People began to see the importance of health. This habit basically also needs to be maintained by the government. The lessons learned from the pandemic can be Jokowi's material to plan the next message. Latency or maintaining a good pattern needs to be practised. Jokowi's next task when the pandemic is over is to educate the public that maintaining a healthy lifestyle is very necessary. Thus, when there is a disaster, people will get used to it. From a total of 145 Jokowi's tweets related to corona, they are categorised into 9 message types, with an explanation and an example of the tweet presented in Table 1.

Table 1: Examples of tweets from each message categorisation

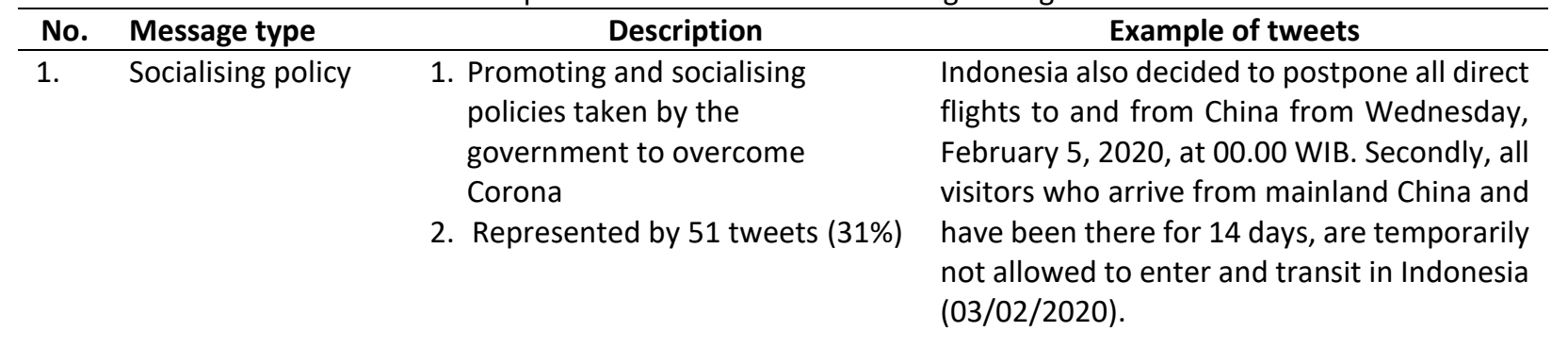

2. Announcement

1. Giving announcements about the current condition of Corona in Indonesia

2. Represented by 31 tweets (21\%)
3. Requesting community
1. Requesting the community to take certain actions to break the chain of the spread of Corona

2. Represented by 13 tweets (9\%) 4. Educating
community
1. Providing knowledge and information about Corona

2. Represented by 13 tweets (9\%)
5. Requesting local government
1. Requesting local governments, ministries and certain institutions to implement policies

2. Represented by 13 tweets (9\%)
Several Southeast Asian countries have confirmed the entry of the coronavirus. We are already alert and standby. A number of 135 thermo scanners have been activated at 135 entrances in Indonesia, and we have prepared 100 referral hospitals for patients with symptoms of infected by this virus (01/27/2020).

WHO recommends that the community wear masks when carrying out activities outside the home. Let's obey the appeal. Please wear a cloth mask that can be washed and worn many times. Surgical and N-95 masks are currently prioritised for doctors and paramedics (04/06/2020).

What is self-isolation? Why 14 days? What can and should not be carried out during self-isolation? This is the basic protocol of self-isolation in handling COVID-19 which is gathered from official sources of WHO and health experts $(03 / 29 / 2020)$.

The government has issued Government Regulation and Presidential Decree to carry out the mandate of the law. I request the regional heads not to make their own policies that are not coordinated. All policies in the regions must be in the corridor of the law and the Government Regulation and Presidential Decree (03/31/2020). 


\begin{tabular}{ll}
\hline 6. Cooperative action & $\begin{array}{l}\text { 1. Carrying out collaborative } \\
\text { actions to overcome Corona }\end{array}$ \\
2. Represented by 12 tweets ( $8 \%)$
\end{tabular}

7. Giving motivation

1. Giving motivation to the community to stay strong during the pandemic

2. Represented by 12 tweets ( $8 \%)$
1. Acknowledgement and appreciation to certain parties

2. Represented by 4 tweets (3\%)
9. Condolence messages
1. Condolence messages to certain parties affected
2. Represented by 1 tweets (1\%)

I have talked by telephone with China President $\mathrm{Xi}$ Jinping. I expressed my condolences and sympathy for the victims of the coronavirus in China. Indonesia will always be together with China in this difficult time. Indonesia believes China can resolve this as soon as possible (03/12/2020).

Indonesia and the majority of other countries are predicted to experience sharp corrections to development targets and economic growth in 2020 due to the Covid19 pandemic. Even so, we still endeavour and work hard. We should not be pessimistic. Insya Allah, we can (04/14/2020).

I truly appreciate the movement of the community who have helped spread information about physical distancing or keeping a safe distance to prevent the spread of the coronavirus. We must work hard, we must unite and work together to face this challenge (03/25/2020).

Deep condolences for the doctors, nurses, and medical personnel who passed away after struggling to take care of the coronavirus patients. On behalf of the country, I express my deepest gratitude for their hard work and dedication in the forefront of handling COVID-19 (03/23/2020).

Even though there are a lot of types of messages used by Jokowi in Twitter, one thing has been the spotlight and that is the problem of coordination. The collaboration is important because according to Hemingway and Gunawan (2018), collaboration between competent institutions can also be used to filter, evaluate and standardise the information to be conveyed to the public. Besides Jokowi, there is actually another official account that is representative of the government, namely Twitter from the Ministry of Health (@KemenkesRI). Jokowi did not mention the Ministry of Health account in his tweets. There should be coordination here, that there is cooperation and notification to the public for example daily updates on the number of sufferers, victims, or others directed to the Ministry of Health. There are different patterns of information provided by Jokowi and the Ministry of Health. Jokowi gave more information regarding what policies were taken by the government, while the Ministry of Health was more directed to the latest update on the condition of the coronavirus in Indonesia. Jokowi also gave a lot of motivation to the community to be equally strong in dealing with this complicated condition. Here, it is reflected that Jokowi has carried out one of the functions of disaster communication, that is conducting public healing.

In the future, every institution should have their own integrated database system (Blake et al., 2019). It will be better when there is coordination between the two institutions so that information obtained by the public will be more comprehensive considering that the 
elements of disaster communication is not just providing information, but also coordinating. The ego must be left behind to create a literated community. It seems that coordination must also be carried out by Jokowi with the government's disaster spokesperson. Thus, in Indonesia, there are too many people who act as opinion leaders. There is Jokowi as the President, the Ministry of Health, and the government-appointed disaster spokesperson. Unfortunately, this government spokesperson often makes blunders by making statements that precisely provoke public emotions. What was conveyed to the public was also not in line with what was expressed by Jokowi and the Ministry of Health on Twitter. However, Jokowi has in fact shared links and information from WHO. Therefore, there is an effort to synchronise what he has to convey with information from the most authorised parties.

Unfortunately, tweets of Jokowi did not really show the coordination between government and academicians or researchers. There is no tweet from Jokowi that mentions about the developments of research related to COVID-19 done by Indonesian researchers. Thus, actually, there are disconnections between academicians and politicians. Yet, according to Vieira, Franco, Restrepo and Abel (2020), in the face of the corona pandemic, it takes a link and matches between knowledge from academicians and action by politicians.

Furthermore, the response of the community to Jokowi's tweets related to COVID-19 were examined. In January, the comments of the followers were still not too many because indeed COVID-19 was just beginning to affect Indonesia. The comments that appear were more related to questioning what policies Jokowi will issue during this pandemic. Entering February, the comments had started to flood Jokowi's tweets because the positive patient numbers of the coronavirus had started to increase. The comments made by netizens tended to show anxiety and questioned the high number of cases. It was only in March that the comments began to surge drastically because the rate of the number of COVID-19 patients in Indonesia was very high, even once ranked the first country in Southeast Asia with the most affected patients. The comments were varied, ranging from praise to insults. Many people questioned the incompetence of the government in dealing with COVID-19. These include policies, such as large-scale social restrictions, the ban of returning home in the month of Ramadhan, social distance, and so on. Comments with the same pattern were still found in April, although the intensity had begun to diminish. Similar to comments, the pattern for retweets and likes is the same. It continued to increase in January and February, reaching a peak in March, and tended to decrease in April.

The large amount of information provided caused a high number of people's comments on each of Jokowi's tweets. Unfortunately, Jokowi does not reply to the comments of his followers. Thus, the engagement between Jokowi and his followers was also not formed. Time limitations certainly make Jokowi unable to reply to all messages, but there should be a number of comments that are prioritised to be answered. Thus, people's questions would be generally answered and there there would be clarity of information. Replying to comments is a follow-up to what Jokowi should have done. In fact, when Jokowi replies to the comments of his followers, it is an effective means of increasing trust in the government. Indicated by Eiser et al. (2012), trust to informers will influence someone to behave when there is a disaster. On the other hand, the information giver must also trust the community that they will carry out the directed advice. In the use of social media, it needs two-way communication (Lovari \& Bowen, 2019). The aims are to collect public aspirations related to disasters, look for rumours, and monitor information so that careful planning and scenarios can be established to deal with emergencies. The responses will also be given 
quickly. Besides, according to Lovari and Parisi (2015), two-way communication is an effort to maintain the quality of relations with the community.

The comments given by people towards Jokowi's tweets should be evaluated. The aim is to map the messages about what the public really wants. Information related to what actually becomes the community's needs. Thus, Jokowi can plan disaster messages better in the future. It should not only be done when the condition is severe. Preparedness by evaluating existing messages is important. Given that Indonesia is a country that is prone to disasters, both natural disasters, pandemics, and man-made, a step forward needs to be taken from now on because basically, there have been frequent disasters. Tsunamis, earthquakes, floods, land immunities, to epidemics such as typhus, malaria do not occur once in Indonesia. The disasters occur many times, even almost every year, there are areas that have disasters. Unfortunately, this is not enough to give awareness to the government. Disaster communication is still unstructured and only reactive when disasters occur. Jokowi should properly reform the existing disaster communication in Indonesia.

One of the efforts is by utilising the experiences of the community related to facing disasters in the past. Local knowledge and community experience must be valued and used as a source of information. Becker, Paton, Johnston, Ronan and McClure (2017) in his research also mentioned if today's experience will affect a person's beliefs about what and how they should act in the future when there is a similar disaster. Also, according to Becker et al. (2019) and Mabon (2020), the experience of affected communities and stakeholders at the local level can also contribute important information and it must be appreciated by the government. Thus, complexity data will be achieved. Bringing together experience, cultural aspects, research and policy is a good strategy. The logic is simple, when community experience is used as a source of information, the community will not hesitate with that information. The people will also feel valued. This is a strategy to guarantee people's perceptions and emotions to follow the government's call. Zhou et al. (2020) even emphasises the importance of business and academic sector participation, so that complex data can be obtained to make comprehensive policies.

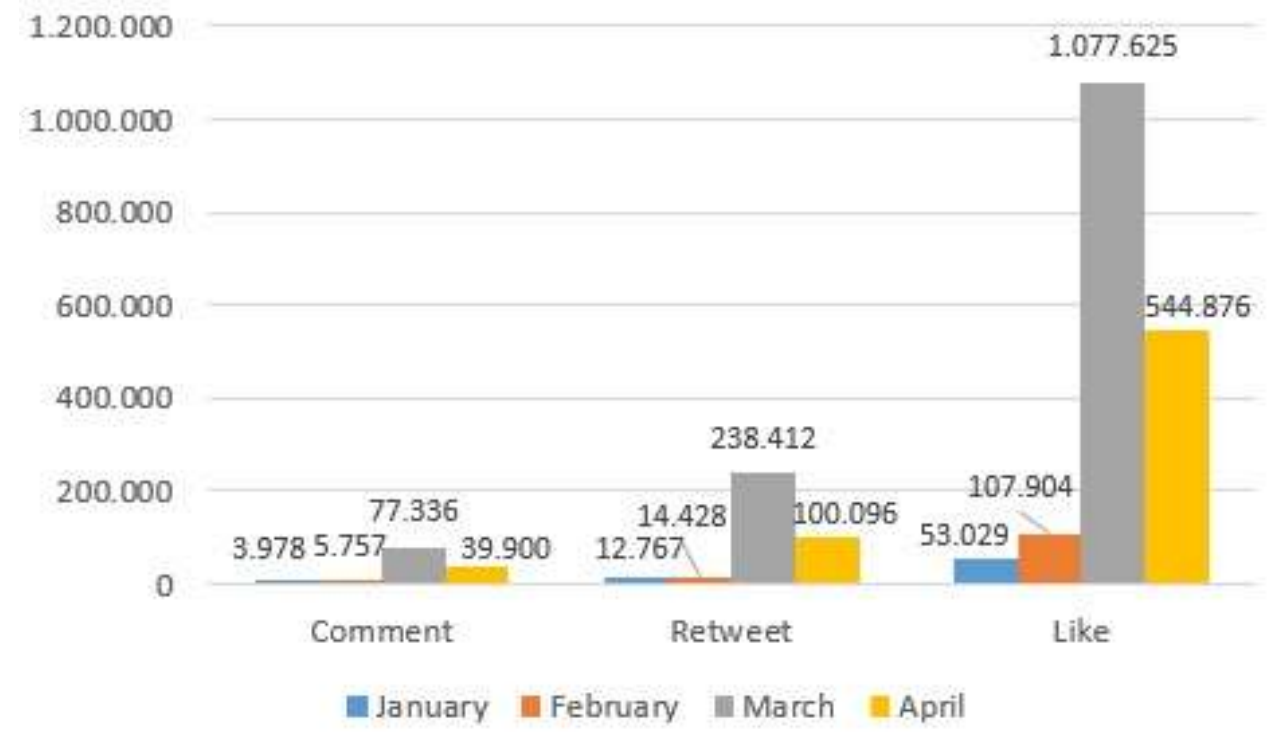

Figure 3: Comparison of comments, retweets, and likes January - April 2020 
One example of the high engagement between Jokowi and his followers is shown by the high rate of retweets and likes obtained. When further analysed, the large number of retweets and likes that Jokowi received is in the tweets with images and videos. There were 80 tweets with images (53\%) and 25 tweets with videos (17\%) in total. Of the 25 videos in Jokowi's tweets, the views are of a huge number. It indicates that the community is interested and curious about the videos uploaded by Jokowi. It can be seen that communication information technology has a role in creating public awareness of disaster issues (Kuppuswamy, 2010). The number of views for each video uploaded by Jokowi is shown in Figure 4.

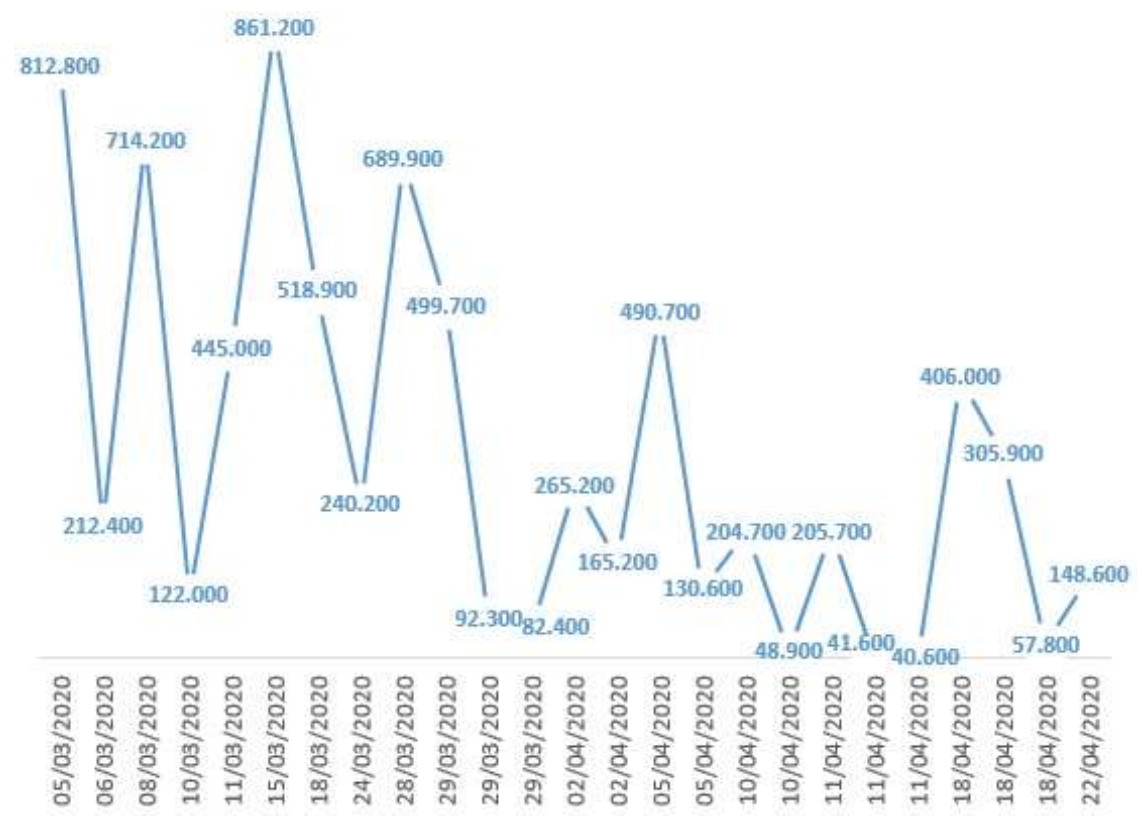

Figure 4: The number of Jokowi's video viewers on Twitter

Based on Figure 4, it can be seen that the fewest viewers were for the video uploaded on April 11, 2020, which was only seen by 40,600 people. The video showed non-fiscal stimulus policies within the framework of the economic recovery program due to the corona pandemic. Meanwhile, the video with the highest viewers was the one uploaded on March 15,2020 , with a total of 861,200 viewers. The video showed an appeal for simple actions that can reduce coronavirus' impact, such as washing hands, keeping a distance, living healthy, avoiding crowds, maintaining a clean environment, and avoiding touching of the face. The average viewers of Jokowi's videos on Twitter are 320,021 views. Each video uploaded by Jokowi was then grouped by the researcher according to the theme in Table 2.

Table 2: Topics of video uploaded by Jokowi on Twitter

\begin{tabular}{|c|c|c|c|}
\hline No. & Topic & Total & Example \\
\hline 1. & $\begin{array}{l}\text { Educating } \\
\text { community }\end{array}$ & 10 & $\begin{array}{l}\text { Video uploaded on March } 05,2020 \\
\text { It shows tips on hand washing, sneezing ethics, avoiding touching the face, } \\
\text { keeping a distance, and wearing a mask. Jokowi explained that the enemy } \\
\text { of the community was not Corona but anxiety, panic, fear, and hoax news. } \\
\text { The community is encouraged to have mutual solidarity and mutual } \\
\text { cooperation. }\end{array}$ \\
\hline
\end{tabular}




\begin{tabular}{|c|c|c|c|}
\hline 2. & Socialising policy & 8 & $\begin{array}{l}\text { Video uploaded on April 2, } 2020 \\
\text { It explains social protection for communities affected by COVID-19. It } \\
\text { ranges from the exemption and electricity payment relief, credit payment } \\
\text { relief, the fulfilment of basic needs, Staple-Food Card, Family Hope } \\
\text { Program, Worker Card, to the addition of handling costs of COVID-19. }\end{array}$ \\
\hline 3. & $\begin{array}{l}\text { Requesting } \\
\text { community }\end{array}$ & 6 & $\begin{array}{l}\text { Video uploaded on April 18, } 2020 \\
\text { The call for self-discipline, started from carrying out activities at home and } \\
\text { maintaining a culture of healthy living. The need to help each other and } \\
\text { not isolate affected patients. Concern and cooperation must be increased. }\end{array}$ \\
\hline 4. & Acknowledgement & 1 & $\begin{array}{l}\text { Video uploaded on April 10, } 2020 \\
\text { Acknowledgements to medical workers, TNI, POLRI and Volunteers. Also, } \\
\text { acknowledgements from the government to the people who have obeyed } \\
\text { the government's appeal to stay at home. }\end{array}$ \\
\hline
\end{tabular}

Furthermore, videos uploaded by Jokowi regarding COVID-19 have various duration, with the shortest duration being 36 seconds. The shortest video, uploaded March 28, 2020, contained an explanation of keeping a distance and studying and worshipping at home. The longest video had a duration of 139 seconds, uploaded on April 5, 2020, which contained an appeal to maintain healthy living habits, avoid crowds, maintain mental health, not break the relationship with other people, and limit the consumption of hoax news. The complete analysis is shown in Figure 5.

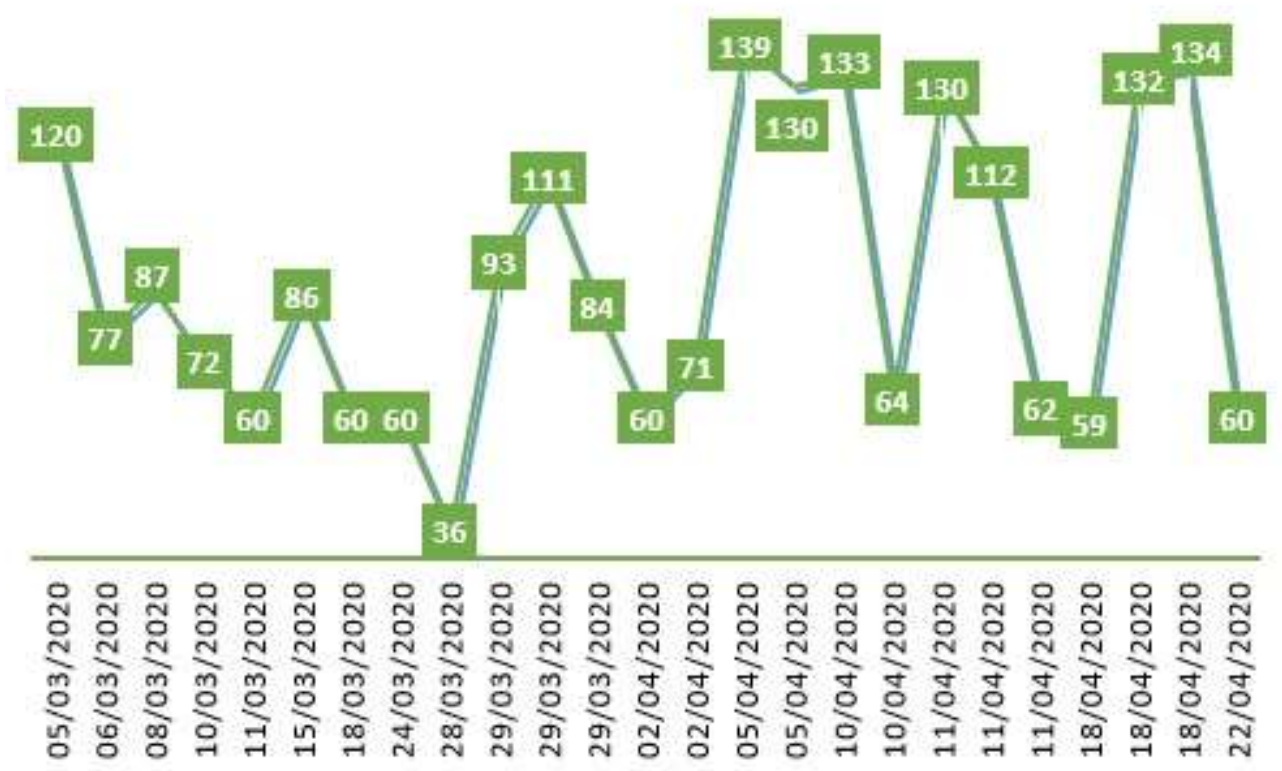

Figure 5: The length of videos uploaded by Jokowi (in seconds)

From the 25 videos and 80 photos uploaded by Jokowi, they not only have various messages, but the presentation also varies. There are several video and photo display techniques used for each upload. Each video and photo is designed according to the message to be conveyed, although there are some photos uploaded that do not match the content of the tweet. Many of the photos uploaded only showed the face of President Jokowi, photos when he was interviewed or during press conferences. Unfortunately, the photos become meaningless because they do not match the severance they wish to convey. For example, in 
a tweet dated March 3, 2020, the photo uploaded to complete the tweet was a photo of Jokowi making a telephone call. However, the content of the tweet was "243 Indonesians from Hubei Province, China, undergoing a period of observation in Natuna. Thank you to all those involved in the evacuation of Indonesian citizens from areas affected by this corona virus outbreak. Thank you to the Natuna community. These are our own brothers". Unfortunately, it is not only one or two tweets that showed such a pattern, but there were several of them. From the results of identification, the types of photos and videos and the total of them will be presented in Table 3. Each of the strategies chosen has different goals and consequences.

Table 3: Video and Photo Used by Jokowi in Twitter during COVID-19 Crisis

\begin{tabular}{|c|c|c|}
\hline \multirow{2}{*}{ No } & \multicolumn{2}{|r|}{ VIDEO } \\
\hline & Type & Information \\
\hline 1. & $\begin{array}{l}\text { Comic strip } \\
\text { (4 videos) }\end{array}$ & $\begin{array}{l}\text { This type of videos obtain rousing welcomes from people because it is very } \\
\text { contemporary and there is a story line presented. }\end{array}$ \\
\hline 2. & $\begin{array}{l}\text { Illustration } \\
\text { (11 videos) }\end{array}$ & $\begin{array}{l}\text { This type of video provides complete information with infographics. It is suitable } \\
\text { for people who do not have much time. }\end{array}$ \\
\hline 3. & $\begin{array}{l}\text { Press conference } \\
\text { ( } 5 \text { videos) }\end{array}$ & $\begin{array}{l}\text { This type of video usually only highlight Jokowi. Models used is like the ethic to do } \\
\text { press conferences. This type of video is even used by Jokowi for campaigns on } \\
\text { television. Thus, the feel of the video is semi-formal. }\end{array}$ \\
\hline 4. & $\begin{array}{l}\text { Shows news } \\
\text { (5 videos) }\end{array}$ & $\begin{array}{l}\text { The fourth type of video is presented as when television shows news. The concept } \\
\text { of coverage is carried by this type of video. }\end{array}$ \\
\hline & \multicolumn{2}{|r|}{ PHOTO } \\
\hline No & Type & Information \\
\hline 1. & $\begin{array}{l}\text { Jokowi activities } \\
\text { (36 photos) }\end{array}$ & $\begin{array}{l}\text { The first photo type/model is showing Jokowi in one frame starting from face, } \\
\text { press conference conditions, online meetings, speeches, and Jokowi's activities. } \\
\text { Here, Jokowi becomes the central point of the photo. Unfortunately, many photos } \\
\text { do not match the contents of the tweet. }\end{array}$ \\
\hline 2. & $\begin{array}{l}\text { Quotation } \\
\text { (37 photos) }\end{array}$ & $\begin{array}{l}\text { The second model is adding quote. This quote was taken from a tweet made by } \\
\text { Jokowi. Even though Jokowi is the central point of the majority, the explanation } \\
\text { given can summarise the contents of the tweets that were to be conveyed. }\end{array}$ \\
\hline 3. & $\begin{array}{l}\text { Cartoon } \\
\text { (7 photos) }\end{array}$ & $\begin{array}{l}\text { The last is photo type/model using illustration of cartoon picture. It is very fresh } \\
\text { and the concept is different from two previous models. }\end{array}$ \\
\hline
\end{tabular}

Moving on to media integration conducted by Jokowi, besides Twitter, Jokowi also uses Instagram, Facebook and television to disseminate his messages. According to Kapoor, Guha, Das, Goswami and Yadav (2020), coordination even needs to be conducted between the government and social media platforms or search engines so that information that is spread to the public has been filtered, checked, and verified for truth. Yet, Jokowi reveals more information on his Twitter. Jokowi's integration is between his social media providing the same information. Jokowi knows who the target of each social media is. Even the videos that are broadcast on television regularly are also the same as what is uploaded on Twitter, neither on Instagram and Facebook. But indeed, the difference is, on Twitter the response became wider and more numerous than Jokowi's other social media. The use of photos and videos uploaded by Jokowi on Twitter was even re-uploaded and disseminated by many people on Twitter. Jokowi basically understands the conditions correctly. Indonesian people do not yet have the habit of reading. Thus, media like photos and videos are used to attract more people's interest. Just like the standard in the use of media, using audio and visualbased media such as video will more quickly increase awareness from the public. Unfortunately, for the use of photos, sometimes it is not in accordance with the content of Twitter, so it is just like a useless photo displayed by Jokowi. Learning from research of Luo, 
Song, Zhang, Wang and Wu (2017) in the use of videos for handling the Ebola pandemic in China, you should not just share the video, but the video will work in the community when there is emotional content in it, for example between affected patients with health workers or family members. In this era, even the use of infographics is needed to make it easier for people to understand messages (Intrieri et al., 2020).

\section{CONCLUSION}

Disaster communication certainly has been conducted in Indonesia in facing the pandemic of the corona virus. As an opinion leader, Jokowi has provided various information, from socialising policies to condolence messages. The use of photos and videos is also carried out by Jokowi to increase public awareness. Unfortunately, disaster communications were not carried out long before the pandemic occurred; it was only actively carried out when the pandemic had claimed many victims. In the future, there will certainly need to be an evaluation related to today's conditions. Thus, there are known patterns of community communication and good habits. With such effort, if there is another pandemic, the government is ready to design a disaster message that minimises the risk of a pandemic. Besides, coordination with many parties in providing information is also important. Finally, regarding the use of hashtag (\#), Jokowi should more often use hashtags for his tweets because the reach of the tweet will be larger. The tweet can become a trending topic and attract people's curiosity.

\section{BIODATA}

Kadhung Prayoga is a lecturer at Extension and Community Development Laboratory, Agribusiness Program, Faculty of Animal and Agricultural Sciences, Diponegoro University, Indonesia. His research interest focuses on extension and communication development. Email: kadhungprayoga@gmail.com 


\section{REFERENCES}

Abunyewah, M., T. Gajendran, \& K. Maund. (2018). Conceptual framework for motivating actions towards disaster preparedness through risk communication. Procedia Engineering, 212, 246-253. https://doi.org/10.1016/j.proeng.2018.01.032

Acar, A. \& Y. Muraki. (2011). Twitter for crisis communication: Lessons learned from Japan's tsunami disaster. International Journal of Web Based Communities, 7(3), 392-402. https://doi.org/10.1504/IJWBC.2011.041206

Al-Garadi, M. A., Khan, M. S., Varathan, K. D., Mujtaba, G., \& Al-Kabsi, A. M. (2016). Using online social networks to track a pandemic: A systematic review. Journal of Biomedical Informatics, 62, 1-11. http://dx.doi.org/10.1016/j.jbi.2016.05.005

Amarul Waqi Suhaimi, Najib Ahmad Marzuki, \& Che Su Mustaffa. (2014). The relationship between emotional intelligence and interpersonal communication skills in disaster management context: A proposed framework. Procedia - Social and Behavioral Sciences, 155, 110 - 114. https://doi.org/10.1016/j.sbspro.2014.10.265

Andrew, S. A., Arlikatti, S., Chatterjee, V., \& Ismayilov, O. (2018). Ebola crisis response in the USA: Communication management and SOPs. International Journal of Disaster Risk Reduction, 31, 243-250. https://doi.org/10.1016/j.ijdrr.2018.04.028

Ao, J., Zhang, P., \& Cao, Y. (2020). Estimating the locations of emergency events from Twitter Streams. Procedia Computer Science, 31, 731-739. https://doi.org/10.1016/j.procs.2014.05.321

Asteria, D. (2016). Optimalisasi komunikasi bencana di media massa sebagai pendukung manajemen bencana. Jurnal Komunikasi Ikatan Sarjana Komunikasi Indonesia, 1(1), 111. https://doi.org/10.25008/jkiski.v1i1.30

Atali, L., \& Gürer, B. (2015). Content analysis of offcial Twitter account of under-20 football world cup. Advances in Physical Education, 5(2), 103-106. https://doi.org/10.4236/ape.2015.52013

Avvisati, G., Sessa, E. B., Colucci, O., Marfè, B., Marotta, E., Nave, R., Peluso, R., Ricci, T., \& Tomasone, M. (2019). Perception of risk for natural hazards in campania region (Southern Italy). International Journal of Disaster Risk Reduction, 40, 1-7. https://doi.org/10.1016/j.ijdrr.2019.101164

Baseri, H., Jarmie, M. Y., \& Anhar, D. (2017). Efektivitas komunikasi badan penanggulangan bencana daerah (BPBD) Kabupaten Banjar dalam mengurangi resiko bencana banjir di Kabupaten Banjar. Jurnal Komunikasi, Bisnis, dan Manajemen, 4(1), 1-19. http://dx.doi.org/10.31602/al-kalam.v4i1.825

Becker, J. S., Paton, D., Johnston, D. M., Ronan, K. R., \& McClure, J. (2017). The role of prior experience in informing and motivating earthquake preparedness. International Journal of Disaster Risk Reduction, 22, 179-193. http://dx.doi.org/10.1016/j.ijdrr.2017.03.006

Becker, J. S., Potter, S. H., McBride, S. K., Wein, A., Doyle, E. E. H., \& Paton, D. (2019). When the earth doesn't stop shaking: How experiences over time influenced information needs, communication, and interpretation of aftershock information during the canterbury earthquake sequence, New Zealand. International Journal of Disaster Risk Reduction, 34, 397-411. https://doi.org/10.1016/j.ijdrr.2018.12.009

Besman, A., Adiputra, A. V., \& Saputra, S. J. (2018). Komunikasi Presiden Joko Widodo dalam vlog \#Baliaman. Jurnal Penelitian Komunikasi, 21(1), 43-56. https://doi.org/10.20422/jpk.v21i1.518 
Blake, D., Marlowe, J., \& Johnston, D. (2017). Get prepared: Discourse for the privileged?. International Journal of Disaster Risk Reduction, 25, 283-388. http://dx.doi.org/10.1016/j.ijdrr.2017.09.012

Blake, D. M., Stevenson, J., Wotherspoon, L., Ivory, V., \& Trotter, M. (2019). The role of data and information exchanges in transport system disaster recovery: A New Zealand case study. International Journal of Disaster Risk Reduction, 39, 1-10. https://doi.org/10.1016/j.ijdrr.2019.101124

Boynton, G. R., Cook, J., Daniels, K., Dawkins, M., Kopish, J., Makar, M., McDavid, W., Murphy, M., Osmundson, J., Steenblock, T., Sudarmawan, A., Wiese, P., \& Zora, A. (2014). The political domain goes to Twitter: Hastags, retweets and URLS. Open Journal of Political Science, 4(1), 8-15. https://doi.org/ 10.4236/ojps.2014.41002

Bowen, S. A. (2016). Clarifying ethics terms in public relations from A to $V$, authenticity to virtue: BledCom special issue of PR review sleeping (with the) media: Media relations. Public Relations Review, 42(4), 564-572. https://doi.org/10.1016/j.pubrev.2016.03.012

Budi, S. (2012). Komunikasi bencana: Aspek sistem (Koordinasi, informasi dan kerjasama). Jurnal ASPIKOM, 1(4), 363-372. http://dx.doi.org/10.24329/aspikom.v1i4.36

Burby, R. J. (2006). Hurricane Katrina and the paradoxes of government disaster policy: Bringing about wise governmental decisions for hazardous areas. The Annals of the American Academy of Political and Social Science, 604(1), 171-191. https://doi.org/10.1177/0002716205284676

Chatfield, A. T., \& Brajawidagda, U. (2013). Twitter early tsunami warning system: A case study in Indonesia's natural disaster management. Proceeding of 46th Hawaii International Conference on System Sciences, 7-10 Jan. 2013. https://doi.org/ 10.1109/HICSS.2013.579

Chew, C., \& Eysenbach, G. (2010). Pandemics in the age of Twitter: Content analysis of tweets during the 2009 H1N1 outbreak. PloS One, 5(11), e14118. https://doi.org/10.1371/journal.pone.0014118

Cindy, \& Sari, W. P. (2019). Citra diri dalam Instagram Jokowi. Koneksi, 3(2), 344-350. http://dx.doi.org/10.24912/kn.v3i2.6380

Comfort, L. K., \& Kapucu, N. (2006). Interorganizational coordination in extreme events: The World Trade Center attacks, September 11, 2001. Natural Hazards, 39, 309-327. https://doi.org/10.1007/s11069-006-0030-x

Comfort, L. K. (2007). Inter-organizational design for disaster management: Cognition, communication, coordination, and control. Journal of Seismology and Earthquake Engineering, 9(1/2), 61-71. Retrieved from https://www.sid.ir/en/journal/ViewPaper.aspx?id=98904

Coombs W. T. (2012). Ongoing crisis communication: Planning, managing, and responding (3rd ed.). Texas, USA: Sage Publication Inc.

Coppola, D., \& Maloney, E. K. (2009). Emergency preparedness strategies for creating a disaster resilient public. Boca Raton: Taylor and Francis Group, LLC.

De Albuquerque J. P., Herfort, B., Brenning, A., \& Zipf, A. (2015). A geographic approach for combining social media and authoritative data towards identifying useful information for disaster management. International Journal of Geographical Information Science, 29(4), 667-689. https://doi.org/10.1080/13658816.2014.996567 
Drina, I., \& Mansur (2017). Karakteristik gaya komunikasi Presiden Jokowi dalam pengambilan kebijakan. Aristo: Sosial Politik Humaniora, 5(2), 318-331. https://doi.org/10.31227/osf.io/8dnwp

Earle P. S., Bowden, D. C., \& Guy, M. (2011). Twitter earthquake detection: Earthquake monitoring in a social world. Annals of Geophysics, 54(6), 708-713. https://doi.org/10.4401/ag-5364

Eiser, J. R., Bostrom, A., Burton, I., Johnston, D. M., McClure, J., Paton, D., van der Pligt, J., \& White, M. P. (2012). Risk interpretation and action: A conceptual framework for responses to natural hazards. International Journal of Disaster Risk Reduction, 1, 5-16. http://dx.doi.org/10.1016/j.ijdrr.2012.05.002

Emma Mirza Wati Mohamad, \& Wan Chooi Han. (2017). Komunikasi pemimpin pendapat dalam isu pembedahan plastik: Suatu analisis kandungan dalam Instagram selebriti media sosial terpilih. Jurnal Komunikasi: Malaysian Journal of Communication, 33(1), 261-279. https://doi.org/10.17576/JKMJC-2017-3301-18

Faulkner, H., Parker, D., Green, C., \& Beven, K. (2007). Developing a translational discourse to communicate uncertainty in flood risk between science and the practitioner. $A M B I O$ : A Journal of the Human Environment, 36(8), 692-704. https://doi.org/10.1579/00447447(2007)36[692:DATDTC]2.0.CO;2

Figueroa, P. M. (2013). Risk communication surrounding the Fukushima nuclear disaster: An anthropological approach. Asia Europe Journal, 11(1), 53-64. https://doi.org/ 10.1007/s10308-013-0343-9

Finau, G., Cox, J., Tarai, J., Kant, R., Varea, R., \& Titifanue, J. (2018). Social media and disaster communication a case study of Cyclone Winston. Pacific Journalism Review, 24(1), 123-137. https://doi.org/10.24135/pjr.v24i1.400

Ginsberg, J., Mohebbi, M. H., Patel, R. S., Brammer, L., Smolinski, M. S., \& Brilliant, L. (2009). Detecting influenza epidemics using search engine query data. Nature, 457(7232), 1012-1014. https://doi.org/10.1038/nature07634

Haddow, G. D., \& Haddow, K. S. (2009). Disaster communications in a changing media world. United Kingdom: Elsevier.

Harlow, S., \& Johnson, T. J. (2011). The Arab Spring| Overthrowing the protest paradigm? How the New York Times, global voices and Twitter covered the Egyptian revolution. International Journal of Communication, 5(16), 1359-1374. Retrieved from http://ijoc.org/index.php/ijoc/article/view/1239

Hemingway, R., \& Gunawan, O. (2018). The natural hazards partnership: A public-sector collaboration across the UK for natural hazard disaster risk reduction. International Journal of Disaster Risk Reduction, 27, 499-511. https://doi.org/10.1016/j.ijdrr.2017.11.014

Hughes, A. L., \& Palen, L. (2009). Twitter adoption and use in mass convergence and emergency events. International Journal of Emergency Management, 6(3/4), 248-260. https://doi.org/10.1504/IJEM.2009.031564

Ichsani, N., \& Amir, A. S. (2017). Twitter of Jokowi: Analyzing president's social network. Advances in Social Science, Education and Humanities Research, 143, 105-108. https://doi.org/10.2991/uicosp-17.2017.30

Intrieri, E., Dotta, G., Fontanelli, K., Bianchini, C., Bardi, F., Campatelli, F., \& Casagli, N. (2020). Operational framework for flood risk communication. International Journal of Disaster Risk Reduction, 46, 1-9. https://doi.org/10.1016/j.ijdrr.2020.101510 
Jain, V. K., \& Kumar, S. (2015). An effective approach to track levels of Influenza-A (H1N1) pandemic in India using Twitter. Procedia Computer Science, 70, 801-807.

Kapoor, A., Guha, S., Das, M. K., Goswami, K. C., \& Yadav, R. (2020). Digital healthcare: The only solution for better healthcare during COVID-19 pandemic?. Indian Heart Journal, 1-4. https://doi.org/10.1016/j.ihj.2020.04.001

Kapucu, N. (2006). Interagency communication networks during emergencies boundary spanners in multiagency coordination. American Review of Public Administration, 36(2), 207-225. https://doi.org/10.1177/0275074005280605

Kashem, M. A. (2006). Communication strategies for disaster preparedness in agriculture sector in Bangladesh. Asia-Pacific Journal of Rural Development, 16(2), 81-100. https://doi.org/10.1177/1018529120060205

Kawasaki, A., Ichihara, N., Ochii, Y., Acierto, R. A., Kodaka, A., \& Zin, W. W. (2017). Disaster response and river infrastructure management during the 2015 Myanmar floods: A case in the Bago River Basin. International Journal of Disaster Risk Reduction, 24, 151159. http://dx.doi.org/10.1016/j.ijdrr.2017.06.004

Kumar, A., \& Sebastian, T. M. (2012). Sentimen analysis on Twitter. International Journal of Computer Science Issues, 9(3), 372-378.

Kuppuswamy, S. (2010). ICT approaches in disaster management: Public awarness, education and training, community resilience in India. In E. Asimakopoulou, \& N. Bessis (Eds.), Advanced ICTs for disaster management and threat detection: Collaborative and distributed frameworks (pp. 22-34). IGI Global. http://doi:10.4018/978-1-61520-9873.ch002

Lampos, V., \& Cristianini, N. (2010). Tracking the flu pandemic by monitoring the social web. Proceeding of the 2nd International Workshop on Cognitive Information Processing, Elba (pp. 411-416). https://doi.org/10.1109/CIP.2010.5604088

Lestari, P., Ramadhaniyanto, B., \& Wardyaningrum, D. (2018). Pemberitaan di media online untuk pengurangan risiko bencana Gunung Sinabung. Jurnal Kajian Komunikasi, 6(1), 106-120. https://doi.org/10.24198/jkk.v6i1.15168

Lewis, S. C., Zamith, R., \& Hermida, A. (2013). Content analysis in an era of big data: A hybrid approach to computational and manual methods. Journal of Broadcasting \& Electronic Media, 57(1), 34-52. https://doi.org/10.1080/08838151.2012.761702

Lindell, M. K., \& Whitney, D. J. (2000). Correlates of household seismic hazard adjustment adoption. Risk Analysis, 20(1), 13-25. https://doi.org/10.1111/0272-4332.00002

Littlejohn, S. W., \& Foss, K. A. (2008). Theories of human communication (9th ed.). USA: Thomson Higher Education.

Louis, C. S., \& Zorlu, G. (2012). Can Twitter predict disease outbreaks?. BMJ, 344, e2353. https://doi.org/10.1136/bmj.e2353

Lovari, A., \& Parisi, L. (2015). Listening to digital publics. Investing citizens' voice and engagement within Italian municipalities' Facebook pages. Public Relations Review, 41(2), 205-213. https://doi.org/10.1016/j.pubrev.2014.11.013

Lovari, A., \& Bowen S. A. (2019). Social media in disaster communication: A case study of strategies, barriers, and ethical implications. Journal Public Affairs, 20, 1-9.

Luo, Y., Song, C., Zhang, H., Wang, Y., \& Wu, H. (2017). Toward sustainable and effective control: Experience of China ebola treatment center in Liberia. Journal of Microbiology, Immunology and Infection, 50, 1-3. http://dx.doi.org/10.1016/j.jmii.2016.04.003 
Mabon, L. (2020). Making climate information services accessible to communities: What can we learn from environmental risk communication research?. Urban Climate, 31, 1-14. https://doi.org/10.1016/j.uclim.2019.100537

Moon, S., Sridhar, D., Pate, M. A., Jha, A. K., Clinton, C., Delaunay, S., Edwin, V., Fallah, M., Fidler, D. P., Garrett, L., Goosby, E., Gostin, L. O., Heymann, D. L., Lee, K., Leung, G. M., Morrison, J. S., Saavedra, J., Tanner, M., Leigh, J. A., Hawkins, B., Woskie, L. R., \& Piot, P. (2015). Will Ebola change the game? Ten essential reforms before the next pandemic. The Report of the Harvard-LSHTM Independent Panel on the Global Response to Ebola. Lancet Health Policy, 386, 2204-2221. https://doi.org/10.1016/S0140-6736(15)00946-0

Mortensen, T. M., Hull, K., \& Boling, K. S. (2017). Really social disaster: An examination of photo sharing on Twitter during the \#SCFlood. Visual Communication Quarterly, 24(4), 219-229. https://doi.org/10.1080/15551393.2017.1388704

Muralidharan, S., Rasmussen, L., Patterson, D., \& Shin, J. H. (2011). Hope for Haiti: An analysis of Facebook and Twitter usage during the earthquake relief efforts. Public Relations Review, 37, 175-177. https://doi.org/10.1016/j.pubrev.2011.01.010

Murthy, D., \& Longwell, S. A. (2013). Twitter and disasters: The uses of Twitter during the 2010 Pakistan floods. Journal Information, Communication, and Society, 16(6), 837855. https://doi.org/10.1080/1369118X.2012.696123

Nair, M. R., Ramya, G. R., \& Sivakumar, P. B. (2017). Usage and analysis of Twitter during 2015 Chennai flood towards disaster management. Procedia Computer Science, 115, 350358. https://doi.org/10.1016/j.procs.2017.09.089

Neppalli, V. K., Caragea, C., Squicciarini, A., Tapia, A., \& Stehle, S. (2017). Sentiment analysis during hurricane Sandy in emergency response. International Journal of Disaster Risk Reduction, 21, 213-222. https://doi.org/10.1016/j.ijdrr.2016.12.011

Neuendorf, K. A. (2002). The content analysis guidebook. Thousand Oaks: Sage Publications.

Nowell, B., \& Steelman, T. (2014). Communication under fire: The role of embeddedness in the emergence and effcacy of disaster response communication networks. Journal of Public Administration Research and Theory, 25(3), 929-952. https://doi.org/10.1093/jopart/muu021

Palen, L., Starbird, K., Vieweg, S., \& Hughes, A. (2010). Twitter-based information distribution during the 2009 Red River Valley flood threat. Bulletin of the American Society for Information Science and Technology, 36(5), 13-17. https://doi.org/10.1002/bult.2010.1720360505

Palttala, P., Boano, C., Lund, R., \& Vos, M. (2012). Communication gaps in disaster management: Perceptions by experts from governmental and non-governmental organizations. Journal of Contingencies and Crisis Management, 20(1), 1-12. https://doi.org/10.1111/j.1468-5973.2011.00656.x

Panuju, R. (2019). The comparison of Jokowi and Prabowo Subianto exposed on YouTube. Jurnal IImu Sosial dan IImu Politik, 22(3), 245-258. https://doi.org/10.22146/jsp.33172

Paton, D., Smith, L., Daly, M., \& Johnston, D. (2008). Risk perception and volcanic hazard mitigation: Individual and social perspectives. Journal of Volcanology and Geothermal Research, 172(3/4), 179-188. https://doi.org/10.1016/j.jvolgeores.2007.12.026

Perdana, K. E., \& Umam, A. H. (2019). Analisis deskriptif sosial media Twitter dalam proses pembentukan Opini Kampanye Gubernur Jawa Barat 2018 dalam 30 hari pertama. Jurnal IImu Politik dan Komunikasi, 9(2), 1-14. https://doi.org/10.34010/jipsi.v9i2 
Polgreen, P. M., Chen, Y., Pennock, D. M., \& Nelson, F. D. (2008). Using internet searches for influenza surveillance. Clinical Infectious Diseases, 47(11), 1443-1448. https://doi.org/10.1086/593098

Purworini, D., \& Sugiyanti, A. (2012). Motif personal branding mahasiswa UMS di Facebook. Journal of KomuniTi, 4(9), 1-11. http://doi.org/10.1017/CBO9781107415324.004

Rahayu, P. B., Asrul, L., \& Akbar, M. (2014). Peran Media cetak lokal dalam mitigasi bencana banjir terhadap kesadaran masyarakat di Kota Makassar. Jurnal Komunikasi Kareba, 3(1), 68-76. http://dx.doi.org/10.31947/kjik.v3i1.572

Raaijmakers, R., Krywkow, J., \& van der Veen, A. (2008). Flood risk perceptions and spatial multi-criteria analysis: An exploratory research for hazard mitigation. Natural Hazards, 46(3), 307-322. https://doi.org/10.1007/s11069-007-9189-z

Ramadani, R., \& Hilmiyah, M. (2019). Pembentukan citra politik di media sosial Twitter. Komunida: Media Komunikasi dan Dakwah, 9(2), 254-268.

Rianti, H. I., \& Esfandaril, D. A. (2019). Strategi komunikasi dinas kebakaran dan penanggulangan bencana Kota Bandung dalam program pembinaan satuan relawan kebakaran Kota Bandung. e-Proceeding of Management, 6(3), 6755-6764.

Riffe, D., Lacy, S., \& Fico, F. G. (2014). Analyzing media messages: Using quantitative content analysis in research (3rd ed.). New York: Routledge Publisher.

Rodriguez, H., Quarantelli, E. L., \& Dynes, R. R. (2007). Handbook of disaster research. New York: Springer Science+Business Media.

Romadhan, M. I. (2018). Personal branding Jokowi dalam mempertahankan brand image melalui video blog YouTube. Meta Communication: Journal of Communication Studies, 3(2), 76-93. http://dx.doi.org/10.20527/mc.v3i2.5446

Roskusumah, T. (2013). Komunikasi mitigasi bencana oleh Badan Geologi KESDM di gunung api merapi prov. D. I. Yogyakarta. Jurnal Kajian Komunikasi, 1(1), 59-68. https://doi.org/10.24198/jkk.v1i1.6031

Saleem, H. M., Xu, Y., \& Ruths, D. (2014). Effects of disaster characteristics on Twitter event Signature. Procedia Engineering, 78, 165-172.

Sandoval-Almazan, R., \& Gil-Garcia, J. R. (2013). Cyberactivism through social media: Twitter, YouTube, and the Mexican political movement "I'm Number 132." Proceedings of 46 Hawaii International Conference on System Sciences, 132 (pp. 1704-1713). http://doi.org/10.1109/HICSS.2013.161

Shahrul Nazmi Sannusi, \& Kamaliah Siarap. (2014). Peranan perhubungan awam dan komunikasi krisis: Kajian terhadap Kementerian Kesihatan Malaysia dalam penanganan wabak Sars. e-BANGI: Journal of Social Sciences and Humanities, 9(2), 125-134. Retrieved from http://ejournal.ukm.my/ebangi/article/view/11095

Shaw, F., Burgess, J., Crawford, K., \& Bruns, A. (2013). Sharing news, making sense, saying thanks: Patterns of talk on Twitter during the Queensland floods. Australian Journal of Communication, 40(1), 23-40.

Signorini, A., Segre, A. M., \& Polgreen, P. M. (2011). The use of Twitter to track levels of disease activity and public concern in the US during the Influenza A H1N1 pandemic. PloS One, 6(5), 1-10. https://doi.org/10.1371/journal.pone.0019467

Skinner, C., \& Rampersad, R. (2014). A revision of communicaton strategies for effectve disaster risk reducton: A case study of the South Durban Basin, Kwazulu-Natal, South Africa. Jàmbá: Journal of Disaster Risk Studies, 6(1), 1-10. http://dx.doi.org/10.4102/jamba.v6i1.132 
Sosiawan, E. A. (2014). Model ideal manajemen teknologi informasi dan komunikasi dalam mendukung operasional penanganan bencana alam. Jurnal Ilmu Pengetahuan dan Teknologi Komunikasi IPTEK-KOM, 17(2), 175-188. http://dx.doi.org/10.33164/iptekkom.17.2.2015.175-188

Syarif, A., Unde, A. A., \& Asrul, L. (2014). Pentingnya komunikasi dan informasi pada implementasi kebijakan penyelenggaran penanggulangan bencana di Kota Makassar. Jurnal Komunikasi KAREBA, 3(3), 142-152. Retrieved from http://journal.unhas.ac.id/index.php/kareba/article/view/583

Szomszor, M., Kostkova, P., \& de Quincey, E. (2009). \#Swineflu: Twitter predicts swine flu outbreak in 2009. Proceedings of the International Conference on Electronic Healthcare, 18-26. https://doi.org/10.1007/978-3-642-23635-8_3

Takahashi, B., Tandoc Jr, E. C., \& Carmichael, C. (2015). Communicating on Twitter during a Disaster: An analysis of Tweets during Typhoon Haiyan in the Philippines. Computers in Human Behavior, 50, 392-398. https://doi.org/10.1016/j.chb.2015.04.020

Takeuchi, Y., Xu, W., Kajitani, Y., \& Okada, N. (2012). Investigating risk communication process for community's disaster reduction with a framework of "communicative survey method". Journal of Natural Disaster Science, 33(1), 49-58. https://doi.org/10.2328/jnds.33.49

Tamitiadini, D., Dewi, W. W. A., \& Adila, I. (2019). Inovasi model mitigasi bencana non struktural berbasis komunikasi, informasi, koordinasi dan kerjasama. Komunikasi, 13(1), 41-52. https://doi.org/10.21107/ilkom.v13i1.5216

Taylor-Clark, K. A., Viswanath, K., \& Blendon, R. J. (2010). Communication inequalities during public health disasters: Katrina's wake. Health Communication, 25(3), 221-229. https://doi.org/10.1080/10410231003698895

Tengku Siti Aisha, Saodah Wok, Aini Maznina A. Manaf, \& Rizalawati Ismail. (2015). Exploring the use of social media during the 2014 flood in Malaysia. Procedia Social and Behavioral Sciences, 211, 931-937. https://doi.org/10.1016/j.sbspro.2015.11.123

Tulloch, J. S. P., Vivancos, R., Christley, R. M., Radford, A. D., \& Warner, J. C. (2019). Mapping Tweets to a known disease epidemiology: A case study of Lyme disease in the United Kingdom and Republic of Ireland. Journal of Biomedical Informatics: $X, 4,1-8$. https://doi.org/10.1016/j.yjbinx.2019.100060

Ulmer, R. R., Sellnow, T. L., \& Seeger, M. W. (2007). Effective crisis communication: Moving from crisis to opportunity. Thousand Oaks: Sage Publication, Inc.

Vergeer, M., \& Hermans, L. (2013). Campaigning on Twitter: Microblogging and online social networking as campaign tools in the $\mathbf{2 0 1 0}$ general elections in the Netherlands. Journal of Computer-Mediated Communication, 18, 399-419. https://doi.org/10.1111/jcc4.12023

Vieira, C. M., Franco, O. H., Restrepo, C. G., \& Abel, T. (2020). COVID-19: The forgotten priorities of the pandemic. Maturitas, 136, 38-41. https://doi.org/10.1016/j.maturitas.2020.04.004

Waters, R. D., Burnett, E., Lamm, A., \& Lucas, J. (2009). Engaging stakeholders through social networking: How nonprofit organizations are using Facebook. Public Relations Review, 35(2), 102-106. https://doi.org/10.1016/j.pubrev.2009.01.006

Wahyudi, F., \& Lubis, E. E. (2016). Pola komunikasi badan penanggulangan bencana daerah Provinsi Riau dalam mencegah dan menanggulangi bencana asap di Riau. JOM FISIP, 3(2), 1-15. Retrieved from https://jom.unri.ac.id/index.php/JOMFSIP/article/view/9379 
Wimmer, R. D., \& Dominick, J. R. (2000). Mass media research: An introduction. United States: Wadsworth Cengage Learning.

Yin, J., Lampert, A., Cameron, M., Robinson, B., \& Power, R. (2012). Using social media to enhance emergency situation awareness. IEEE Intelligent Systems, 27(6), 52-59. https://doi.org/10.1109/MIS.2012.6

Yuniar. (2018). Analisis informasi mitigasi bencana Gunung Sinabung dalam perspektif komunikasi publik di Kabupaten Karo. Jurnal Kapita Selekta Geografi, 1(1), 1-6. Retrieved from http://ksgeo.ppj.unp.ac.id/index.php/ksgeo/article/view/47

Zhou, C., Su, F., Pei, T., Zhang, A., Du, Y., Luo, B., Cao, Z., Wang, J., Yuan, W., Zhu, Y., Song, C., Chen, J., Xu, J., Li, F., Ma, T., Jiang, L., Yan, F., Yi, J., Hu, Y., Liao, Y., \& Xiao, H. (2020). COVID-19: Challenges to GIS with big data. Geography and Sustainability, 1-11. https://doi.org/10.1016/j.geosus.2020.03.005

Zook, M. A., Graham, M., Shelton, T., \& Gorman, S. (2010). Volunteered geographic information and crowdsourcing disaster relief: A case study of the Haitian Earthquake. World Medical and Health Policy, 2(2), 7-33. https://doi.org/10.2202/1948-4682.1069 